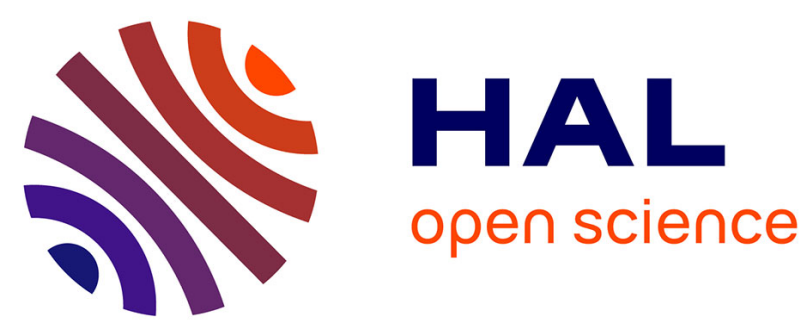

\title{
Effect of reverse osmosis concentration coupled with drying processes on polyphenols and antioxidant activity obtained from Tectona grandis leaf aqueous extracts
}

Emmanuel N. Koffi, Emmanuelle Meudec, Félix A. Adjé, Paul R. Lozano, Yves F. Lozano, Yves-Alain Bekro

\section{To cite this version:}

Emmanuel N. Koffi, Emmanuelle Meudec, Félix A. Adjé, Paul R. Lozano, Yves F. Lozano, et al.. Effect of reverse osmosis concentration coupled with drying processes on polyphenols and antioxidant activity obtained from Tectona grandis leaf aqueous extracts. Journal of Applied Research on Medicinal and Aromatic Plants, 2015, 2 (2), pp.54-59. 10.1016/j.jarmap.2015.03.001 . hal-01982717

\section{HAL Id: hal-01982717 https://hal.science/hal-01982717}

Submitted on 15 Jan 2019

HAL is a multi-disciplinary open access archive for the deposit and dissemination of scientific research documents, whether they are published or not. The documents may come from teaching and research institutions in France or abroad, or from public or private research centers.
L'archive ouverte pluridisciplinaire HAL, est destinée au dépôt et à la diffusion de documents scientifiques de niveau recherche, publiés ou non, émanant des établissements d'enseignement et de recherche français ou étrangers, des laboratoires publics ou privés. 


\title{
Effect of reverse osmosis concentration coupled with drying processes on polyphenols and antioxidant activity obtained from Tectona grandis leaf aqueous extracts
}

\author{
Emmanuel N. Koffi ${ }^{\mathrm{a}, *}{ }^{*}$ Emmanuelle Meudec ${ }^{\mathrm{b}}$, Félix A. Adjéc $^{c}$, Paul R. Lozano ${ }^{\mathrm{d}}$, \\ Yves F. Lozano ${ }^{\mathrm{d}}$, Yves-Alain Bekro ${ }^{\mathrm{a}}$ \\ a Université Nangui Abrogoua, Laboratoire de Chimie Bio Organique et de Substances Naturelles (LCBOSN), 02 BP 801 Abidjan 02, Cote \\ d'Ivoire \\ b INRA, UMR SPO (Sciences pour l'œnologie), Plateforme Polyphenols, 34060 Montpellier cedex 1, France \\ ' INP-HB, Laboratoire de procédés Industriels, de Synthèse, de l'Environnement et des Energies Nouvelles (LAPISEN), Yamoussoukro, Cote \\ d'Ivoire \\ d CIRAD, UMR-110 INTREPID (INTensification Raisonnée et Ecologique pour une Pisculture Durable), TA B 110-16, 73 rue J. F. Breton, \\ 34098 Montpellier cedex 5, France
}

\section{A R T I C L E I N F O}

\section{Article history:}

Received 19 October 2014

Accepted 2 March 2015

Available online 25 April 2015

\section{Keywords:}

Tectona grandis leaf extracts

Reverse osmosis concentration

Freeze-drying

Spray-drying

Polyphenols

Antioxidant capacity

\begin{abstract}
A B S T R A C T
Tectona grandis leaf extracts obtained at pilot scale processes (ultrasound-assisted extraction, cross-flow microfiltration, reverse osmosis concentration) contains phenolic compounds that exhibit antioxidant properties. The final reverse osmosis concentrate extract presented higher content of polyphenol $\left(21,080 \pm 117 \mu \mathrm{mol} \mathrm{g}^{-1} \mathrm{GAE}\right)$ and antioxidant capacity $\left(8490 \pm 29 \mu \mathrm{mol} \mathrm{g}^{-1} \mathrm{TE}\right)$ comparatively to crude extract $\left(1300 \pm 12 \mu \mathrm{mol} \mathrm{g}^{-1}\right.$ GAE for polyphenol and $430 \pm 2 \mu \mathrm{mol} \mathrm{g}^{-1}$ TE for antioxidant activity) or cross flow microfiltration extract $\left(1170 \pm 10 \mu \mathrm{molg}^{-1} \mathrm{GAE}\right.$ for polyphenol and $400 \pm 10 \mu \mathrm{molg}^{-1} \mathrm{TE}$ for antioxidant). The concentration factors of polyphenol and antioxidant capacity were 18 and 21, respectively. High-performance liquid chromatography (HPLC) coupled to electrospray ionization mass spectrometry (ESI-MS) detection negative ion mode has been used to identify and characterized polyphenols in the concentrate extract of $T$. grandis leaves. Seven phenolic acids and flavonoids were characterized. Verbascoside (phenolic acid) was described as the most abundant phenolic compounds in this concentrate extract. Two drying technologies (freeze-drying and spray-drying) were used to obtained stable powder from concentrate extract. The effect of these drying technologies on phenolic compounds and antioxidant activity were studied. Freeze-drying presented a good recovery of phenolic compounds and antioxidant capacity. This drying technology could be used for preservation of $T$. grandis extract.
\end{abstract}

(c) 2015 Elsevier GmbH. All rights reserved.

\section{Introduction}

Tectona grandis L. (Verbenaceae), commonly named teak is used in folk medicine for a wide variety of

\footnotetext{
* Corresponding author. Tel.: +225 07077180.

E-mail address: emmanuelkoffi@ymail.com (E.N. Koffi).
}

remedies (Aradhana et al., 2010; Tra Bi et al., 2008). Several pharmacological activities have been attributed to $T$. grandis extracts, mainly antidiabetic activity (Ghaisas et al., 2010; Pooja and Samanta, 2011) and antioxidant activity (Naira and Karvekar, 2011; Rao et al., 2011). Previous studies revealed the presence of phenolic compounds on the extracts of $T$. grandis leaves such flavonoids and phenolic acids (Naira and Karvekar, 2010; Shukla et al., 2010). 
Polyphenols are of a great interest due to their beneficial effect for human health: prevention and treatment of certain cancers, inflammatory diseases, cardiovascular and neurodegenerative diseases (Pandey and Rizvi, 2009). They have often been identified as active principles of numerous folk herbal medicines (Apak et al., 2007).

Local populations of Côte d'Ivoire has been extracted these bioactive compounds from plant materials by decoction or infusion with water as solvent. Many studies have showed that polyphenol contents in aqueous extracts were unstable during storage (Chedea et al., 2011; Malick and Bradford, 2008). In this study, a pilot plant scale processing of dried plant leaves was set to produce stabilized extracts in a powder form to increase the shelf-life of the ready to use medicinal product. The process includes several steps such as ultrasound-assisted water-maceration of dried leaves, membrane filtration and concentration of the extract and stabilization of the concentrate extract by spray-drying or freeze-drying. The effect of stabilization processes on polyphenol contents and antioxidant capacity was studied. Polyphenol contents were also identified and characterized by HPLC coupled to UV-vis diode array detection and mass spectrometry with electrospray ionization (LC/DAD/ESI-MS ${ }^{2}$ ).

\section{Material and methods}

\subsection{Plant material}

Leaves of $T$. grandis were collected from teak plantations in the centre of Côte d'Ivoire around Yamoussoukro area. After harvesting, the leaves were brought to LAPISEN laboratory (Yamoussoukro, Côte d'Ivoire) for drying at an average temperature of $30^{\circ} \mathrm{C}$ during day time, and kept away from direct sun exposure under an open-sided shed. The dried leaves were packed in plastic bags and shipped to CIRAD laboratory (Montpellier, France), where they were stored at $4{ }^{\circ} \mathrm{C}$ until processed and analyzed.

\subsection{Chemicals}

All reagents were of analytical grade. Sodium hydroxide $(\mathrm{NaOH})$, sodium carbonate salt $\left(\mathrm{Na}_{2} \mathrm{CO}_{3}\right)$, monohydrated citric acid, dihydrated monosodium phosphate $\left(\mathrm{NaH}_{2} \mathrm{PO}_{4}\right.$, $\left.2 \mathrm{H}_{2} \mathrm{O}\right)$, disodium hydrogen phosphate $\left(\mathrm{Na}_{2} \mathrm{HPO}_{4}\right)$, FolinCiocalteu's phenol reagent were purchased from Carlo Erba (Spain).

Gallic acid, quercetin, trolox (6-hydroxy-2,5,7,8tetramethylchroman-1-carboxylic acid), fluorescein, AAPH (2,2'-azobis (2-methylpropanimidamide) dihydrochloride), luteolin, caffeic and chlorogenic acids were purchased from Sigma-Aldrich (Germany).

\subsection{Pilot plant extraction and extract concentration}

Ultrasound-assisted extraction of dried leaves $(1.65 \mathrm{~kg}$ ) was performed with $100 \mathrm{~L}$ of acidified tap water $\left(\mathrm{H}_{2} \mathrm{O}\right.$, $0.01 \mathrm{~N}$ citric acid) during $40 \mathrm{~min}$ using ultrasonic (US) pilot plant unit equipped with anchor-shape and slow-motion stirrer ( $40 \mathrm{kHz}$ US frequency, 200-500 W US variable power, REUS, Contes, France). The water extract obtained was filtered using a nylon cloth to give a crude extrat (CE), which was then clarified by Cross-flow microfiltration (CFM) to give a CFM permeate volume $\left(\mathrm{V}_{\mathrm{CFM}}\right.$ ) of about $92 \mathrm{~L}$, which was then concentrate by reverse osmosis (RO) at a constant trans-membrane pressure of 40 bar. The final volume of the RO concentrate extract obtained $\left(V_{R O}\right)$ was generally $3 \mathrm{~L}$, which was close to that of the dead volume of the RO pilot plant unit. The performance of this RO concentration step was characterized by calculating concentration factor:

$\mathrm{CF}=\frac{\mathrm{TSP}_{\mathrm{RO}}}{\mathrm{TSP}_{\mathrm{CFM}}}$

where $\mathrm{CF}$, concentration factor; $\mathrm{TSP}_{\mathrm{RO}}$, total soluble polyphenol content in the RO concentrate and $\mathrm{TS}_{\mathrm{CFM}}$, total soluble polyphenol content in the TSP $\mathrm{CFM}_{\mathrm{C}}$ permeates.

\subsection{Freeze drying process}

Reverse osmosis (RO) concentrate extract were frozen at $-30^{\circ} \mathrm{C}$ in cold room and dried using freeze dryer (type cryonext, France) for $48 \mathrm{~h}$. Sample temperature was set at $-80^{\circ} \mathrm{C}$ and the pressure was set less than 0.2 bar.

\subsection{Spray drying process}

RO concentrate extracts were dried using spray dryer (Minispray Dryer, B-290 Minispray Dryer) with $120^{\circ} \mathrm{C}$ of an inlet air temperature and $60^{\circ} \mathrm{C}$ of an outlet air temperature.

\subsection{Total polyphenol content}

Total polyphenol content was determined by colorimetry, using the Folin-Ciocalteu (F-C) method (Singleton and Rossi, 1965; Wood et al., 2002). To $30 \mu \mathrm{L}$ sample extract, $2.5 \mathrm{~mL}$ of diluted Folin-Ciocalteu's phenol reagent $(1 / 10)$ were added. After 2 min of incubation in the dark at room temperature, $2 \mathrm{~mL}$ of aqueous sodium carbonate $\left(75 \mathrm{~g} \mathrm{~L}^{-1}\right)$ were added. After slight stirring, the mixture was put in a water bath at $50^{\circ} \mathrm{C}$ for $15 \mathrm{~min}$ then cooled down. The absorbance was measured at $\lambda=760 \mathrm{~nm}$ using a UV-vis spectrophotometer (Jenway 6705, Barloworld Scientific SAS, France). Total polyphenol content was expressed as $\mu \mathrm{mol}$ GAE (Gallic Acid Equivalent) per gram of dried leaves water-extracted. Samples were analyzed in triplicate.

\subsection{Antioxidant capacity}

Antioxidant capacity was carried by oxygen radical absorbance capacity (ORAC) assay. The ORAC method used was described by Ou et al. (2001). The automated ORAC assay was carried out on a VICTOR ${ }^{\mathrm{TM}} X 3$ Multilabel Plate Reader (Perkin-Elmer, USA) with fluorescence filters for an excitation wavelength at $485 \mathrm{~nm}$ and an emission wavelength at $535 \mathrm{~nm}$ (Zulueta et al., 2009). The reaction was performed at $37^{\circ} \mathrm{C}$ as the reaction was started by thermal decomposition of AAPH in $75 \mathrm{mmol} \mathrm{L}^{-1}$ phosphate buffer ( $\mathrm{pH}$ 7.4). A stock solution of fluorescein (FL) was prepared by weighing $22 \mathrm{mg}$ of FL, dissolving it in $100 \mathrm{~mL}$ of phosphate buffer (PBS) ( $75 \mathrm{mmol} \mathrm{L}^{-1}, \mathrm{pH} 7.4$ ), and then storing it in complete darkness under refrigeration conditions. The 
working solution ( $78 \mathrm{nmol} \mathrm{L}^{-1}$ ) was prepared daily by dilution of $0.334 \mathrm{~mL}$ of the stock solution in $25 \mathrm{~mL}$ of phosphate buffer. The AAPH radical $\left(221 \mathrm{mmol} \mathrm{L}^{-1}\right)$ was prepared daily by taking $0.6 \mathrm{~g}$ of AAPH and making it up to $10 \mathrm{~mL}$ with PBS. $100 \mu \mathrm{L}$ of FL and $100 \mu \mathrm{L}$ of diluted sample, PBS or standard (Trolox 5-50 $\mu \mathrm{mol} \mathrm{L}^{-1}$ ) were placed in each well of a 96 well-plate and pre-incubated during $15 \mathrm{~min}$. After, $50 \mu \mathrm{L}$ of AAPH were added into the wells. The fluorescence was measured every minute during $60 \mathrm{~min}$ with emission and excitation wavelength of 485 and $535 \mathrm{~nm}$, respectively, which was maintained at $37^{\circ} \mathrm{C}$. The ORAC values were calculated as area under the curve (AUC) and were expressed as $\mu \mathrm{mol}$ TE (Trolox Equivalent) per gram of dried leaves water-extracted. Samples were analyzed in triplicate.

\subsection{HPLC-ESI-SM analyses}

An ion trap mass spectrometer (Bruker Daltonics Amazon, Bremen, Germany) was connected via an electrospray ionization (ESI) interface for high performance liquid chromatography-tandem mass spectrometry (HPLC-SM ${ }^{2}$ ) to UPLC-DAD (Waters Acquity, Milford, MA) equipped with a RP18 column (Acquity BEH column, $10 \mathrm{~mm} \times 1 \mathrm{~mm}$, $1.7 \mu \mathrm{m}$ particle size, Waters, Milford, MA) placed in a controlled temperature oven set at $35^{\circ} \mathrm{C}$. The injection volume was $0.5 \mu \mathrm{L}$. The mobile phase was a binary solvent system of $A$ (water:formic acid, 99:1, v/v) and B (methanol:formic acid, 99:1, v/v). The multi-linear gradient profile was: $2 \%$ B from start to $1 \mathrm{~min}, 2-30 \% \mathrm{~B}$, from 1 to $10 \mathrm{~min}, 30 \% \mathrm{~B}$ from 10 to $12 \mathrm{~min}, 30-75 \% \mathrm{~B}$ from 12 to $25 \mathrm{~min}, 75-90 \%$ B from 25 to $30 \mathrm{~min}$, and $90 \%$ B from 30 to $35 \mathrm{~min}$. The elution flow rate was set at $0.08 \mathrm{~mL} \mathrm{~min}^{-1}$. The mass spectrometer operated in negative ion mode (capillary voltage: $2.5 \mathrm{kV}$; end plate off set: $-500 \mathrm{~V}$; temperature: $200^{\circ} \mathrm{C}$; nebulizer gas: $10 \mathrm{psi}$ and dry gas: $5 \mathrm{~L} \mathrm{~min}^{-1}$; collision energy for fragmentation in MS/MS set at 1). Polyphenols were detected at $280 \mathrm{~nm}$. $\mathrm{UV}$-vis spectra were recorded from $210 \mathrm{~nm}$ to $600 \mathrm{~nm}$. The data analysis software was used for data acquisition and processing.

\subsection{Statistical analysis}

Results were expressed as mean \pm standard deviation of three replicate. Data were evaluated by one-way analysis of variance (ANOVA) using Statistica 7.1 (StatSoft, Inc., USA) solfware. Newman-keuls test was performed to determine significant differences at $p<0.05$.

\section{Results and discussion}

\subsection{Extraction and concentration process}

The ultrasound-assisted extract of $T$. grandis leaves obtained in pilot scale was clarified by cross flow microfiltration (CFM) and then concentrated by reverse osmosis (RO). Table 1 presents total polyphenol and antioxidant content from the three co-products (crude extractCFM extract-concentrate RO retentate). The amounts of polyphenols and antioxidants were higher in RO concentrate extract than crude extract or CFM extract. The
Table 1

Total polyphenol contents and antioxidant activity of $T$. grandis L. leaf extract.

\begin{tabular}{lcc}
\hline Process co-products & $\begin{array}{l}\text { Total polyphenols } \\
\left(\mu \mathrm{molg}^{-1} \mathrm{GAE}\right)\end{array}$ & $\begin{array}{l}\text { Antioxidant } \\
\text { capacity } \\
\left(\mu \mathrm{molg}{ }^{-1} \mathrm{TE}\right)\end{array}$ \\
\hline Crude extract & $1300 \pm 12^{\mathrm{a}}$ & $430 \pm 2^{\mathrm{a}}$ \\
CFM permeate & $1170 \pm 10^{\mathrm{a}}$ & $400 \pm 10^{\mathrm{a}}$ \\
RO concentrate & $21,080 \pm 117^{\mathrm{b}}$ & $8490 \pm 29^{\mathrm{b}}$ \\
CF & 18 & 21 \\
\hline
\end{tabular}

GAE, gallic acid equivalent; TE, trolox equivalent; CFM, cross flow membrane; RO, reverse osmosis; CF, concentration factor. For each column, letters equals indicate that the means difference is not significant at $p<0.05$.

concentration factors (CF) of total polyphenol and antioxidant capacity were 18 and 21; respectively. The amount of polyphenols and antioxidant capacity obtained in CFM extract was lower than those obtained in crude extract. Statistical analysis did not show significant differences at $p<0.05$ between the considered values. These results indicate that concentration process did not degrade polyphenols and antioxidant activity from $T$. grandis leaves, as found by Adjé et al. (2012).

\subsection{Identification of phenolic compounds from concentrate RO extract}

HPLC-DAD profile of polyphenols from RO concentrate extract was shown in Fig. 1. Phenolic acids and flavonoids were identified.

\subsubsection{Phenolic acids identification}

The molecular structures of phenolic acids in $T$. grandis leaves extract, were confirmed on the basis of their LC-MS fragmentation MS, MS ${ }^{2}$ and $\mathrm{MS}^{3}$ and on the shape of their UV-vis spectra as shown in Table 2, and were compared with previous published studies. Seven phenolic acids were identified in aqueous extract of $T$. grandis leaves.

Compound 1 gave $[\mathrm{M}-\mathrm{H}]^{-}$at $m / z 153$ with $\mathrm{UV}-\mathrm{vis} \lambda_{\max }$ at 260 and $294 \mathrm{~nm}$ spectra are typical for protocatechuic acid. Compounds 2 and 7 had $[\mathrm{M}-\mathrm{H}]^{-}$at $m / z=353$. The $\mathrm{MS}^{2}$ fragmentation patterns produced ions at $\mathrm{m} / \mathrm{z}$ $191,179,135$, corresponding to 3-O-caffeoylquinic acid (Compound 2). The fragmentation at $m / z 191$ ([M-H-162]), 179 ([M-H-174]), 173 ([M-H-180]) and 135 ([M-H-218]) were characteristics of 4-O-caffeoylquinic acid (Stalmach et al., 2009). The product ions $m / z 191$ for quinic acid and 179 for caffeic acid revealed the constituent of 3-CQA prior to condensation. Loss of a caffeoyl moiety yielded the other dominant fragment ion $m / z$ 173. The structure of 4-CQA (Compound 7) was confirmed by co-elution with the standard. Compound 3 was identified as 2-Ocaffeoylhydroxycitric acid with $m / z^{-}$at 369 and $\mathrm{MS}^{2}$ at 207 after loss of 162 amu (caffeoyl moiety). A similar fragmentation was reported by Parveen et al. (2008). Compound 4 with $[\mathrm{M}-\mathrm{H}]^{-}$at $m / z 487$ and a fragment at 179 (caffeic acid) obtained after loss $308 \mathrm{amu}$. In $\mathrm{MS}^{2}$ fragmentation, it observed that compound 3 lost neutral mass ion at $\mathrm{m} / \mathrm{z}$ 44 corresponding to loss of $\mathrm{CO}_{2}$. So, compound should be identified as caffeoyl acid derivative. Compound 6 , which UV-vis $\lambda_{\max }$ at $325 \mathrm{~nm}$ spectra and $\mathrm{m} / z^{-}$at 179 are 


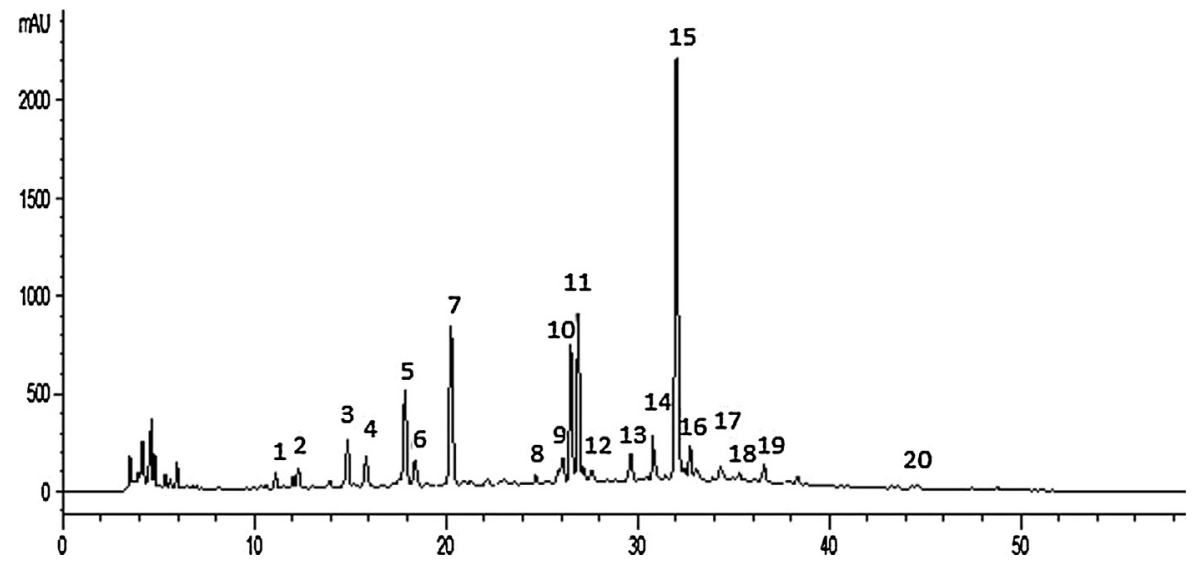

Fig. 1. HPLC chromatogram obtained at $280 \mathrm{~nm}$ for aqueous extract of $T$. grandis leaves.

Table 2

LC-MS data obtained from the analysis of $T$. grandis leaves extract.

\begin{tabular}{|c|c|c|c|c|c|c|c|}
\hline Peak & Compounds & $\lambda \max$ & MW & {$\left[\mathrm{M}-\mathrm{H}^{+}\right]$} & Fragments & Neutral loss & Percentage (\%) \\
\hline 1 & Protocatechuic acid & 296 & 154 & 153 & & & 0.9 \\
\hline 2 & 3-O-caffeoyl quinic (3-CQA) & 324 & 354 & 353 & $191-179-(135)$ & & 1.3 \\
\hline 3 & 2-O-caffeoylhydroxycitric acid & 326 & 370 & 369 & 207 & 162 & 3.2 \\
\hline 4 & Caffeoyl acid derivative & 326 & 488 & 487 & 179-135 & $308-44$ & 2.2 \\
\hline 6 & Caffeic acid & 297sh-325 & 180 & 179 & & & 1.8 \\
\hline 7 & 4-O-caffeoyl quinic (4-CQA) & 326 & 354 & 353 & 173-191-179-135 & $180-162-174-218$ & 12.2 \\
\hline 10 & Apigenin7-O-diglucuronide & $269-330$ & 624 & 623 & $447(271)$ & $176(2 \times 176)$ & 8.0 \\
\hline 11 & Luteolin 7-O-diglucuronide & $255-349$ & 638 & 637 & $351-(285-193)$ & $286-(352-444)$ & 9.5 \\
\hline 14 & luteolin 7-O-glucuronide & 289sh-333 & 462 & 461 & 285 & 176 & 2.8 \\
\hline 15 & Verbascoside & 289sh-333 & 624 & 623 & $461-315$ & $162-308$ & 31 \\
\hline 16 & Luteolin diglucuronide & $269-340$ & & 637 & $461-285$ & $176^{*} 2$ & 2.3 \\
\hline 17 & Apigenin glucuronide & $266-336$ & 446 & 445 & 269 & 176 & 1.0 \\
\hline 19 & Luteolin glucuronide & $268-340$ & 462 & 461 & 285 & 176 & 0.9 \\
\hline 20 & Luteolin & $254-349$ & 286 & 285 & $175-239-241$ & & 0.4 \\
\hline
\end{tabular}

typical for caffeic acid (Fernandes et al., 2011). The nature of this compound was confirmed by co-elution with the standard. Caffeic acid was already reported in $T$. grandis extract (Nayeem and Karvekar, 2010). Compound 15 gave $[\mathrm{M}-\mathrm{H}]^{-}$at 623 and fragments at $461 \mathrm{amu}$ and $315 \mathrm{amu}$ after loss of 162 amu (caffeoyl moiety) and 308 amu (rhamnoside moiety), respectively. Its UV-vis spectrum showed a maximal at $\lambda_{\max }=333$ with a shoulder at 289sh typical for verbascoside (Petreska et al., 2011). Verbascoside was identified as the most abundant compound (30\% of total peak area at $280 \mathrm{~nm}$ ) in extract of $T$. grandis leaves. Previous study showed significant antihyperglycemic activity of verbascoside (Shukla et al., 2010). This property can be beneficial for the treatment of diabetics. Other studies assigned to this compound antioxidant, anti-inflammatory, photo-protective and anti-gastric ulcer activities (Singh et al., 2010; Vertuani et al., 2011). So, leaves which are the discharges of wood industries could be interested by pharmaceutical or cosmetic industries.

\subsubsection{Flavonoid identification}

Seven flavonoids were identified on between basis of HPLC coupled to UV-vis diode array detection and mass spectrometry with electrospray ionization (LC/DAD/ESI$\mathrm{MS}^{2}$ ).

The molecular ion peak $[\mathrm{M}-\mathrm{H}]^{-}$for the compound 11 was $m / z 623$ with fragments ions at $m / z 447\left([\mathrm{M}-\mathrm{H}-176]^{-}\right)$ and 271 ([M-H-176-176 $\left.]^{-}\right)$, typical fragments of apigenin 7-O-diglucuronide (Meng et al., 2006). Compounds 12 and 16 were assigned to luteolin diglucuronide. HPLC-SM

Table 3

Effect of drying processes on polyphenol contents and antioxidant activity.

\begin{tabular}{|c|c|c|c|c|}
\hline \multirow[t]{2}{*}{ Co-product } & \multicolumn{2}{|l|}{ Polyphenol } & \multicolumn{2}{|l|}{ Antioxidant } \\
\hline & Content $\left(\mu \mathrm{mol} \mathrm{g}^{-1} \mathrm{GAE}\right)$ & Recovery (\%) & Capacity ( $\left.\mu \mathrm{molg}^{-1} \mathrm{TE}\right)$ & Recovery (\%) \\
\hline RO concentrate & $21,080 \pm 117^{a}$ & 100.0 & $8490 \pm 29^{a}$ & 100.0 \\
\hline Powder 1 & $18,170 \pm 75^{b}$ & 86.19 & $6980 \pm 12^{b}$ & 82.21 \\
\hline Powder 2 & $13,960 \pm 38^{c}$ & 66.22 & $5210 \pm 5^{c}$ & 61.36 \\
\hline
\end{tabular}

RO, reverse osmosis; GAE, gallic acid equivalent; TE, trolox equivalent. For each column, letters equals indicate that the means difference is not significant at $p<0.05$. 
characteristics indicated in $\mathrm{SM}^{1}, m / z$ at $637[\mathrm{M}-\mathrm{H}]^{-}$with fragments ions at $\mathrm{m} / \mathrm{z} 461\left([\mathrm{M}-\mathrm{H}-176]^{-}\right.$and 285 ([M-H$\left.(2 \times 176)]^{-}\right)$, respectively after loss of one glucuronid acid and two glucuronid acids. Compound 14 with $[\mathrm{M}-\mathrm{H}]^{-}$at $\mathrm{m} / \mathrm{z} 461$ and a fragment at 285 (luteolin) obtained after loss 176 (glucuronic acid) was assigned to luteolin 7-Oglucuronide. A similar fragmentation of the compound was reported by Johnson et al. (2011) in Russelia equisetiformis extract. Compound 18 was identified as apigenin glucuronide showed the loss of a glucuronic acid $(\mathrm{m} / \mathrm{z}$ 176) and produced the predominant fragment at $m / z 269$ corresponding to deprotonated apigenin. Similar fragmentation of the compound was reported by Zimmermann et al. (2011) when analysing Salvia officinalis L. extracts. Compound 19 was luteolin glucuronide with $m / z^{-}$at 461 and $\mathrm{MS}^{2}$ ion at 285 (luteolin) due to the loss of $176 \mathrm{amu}$ corresponding to glucuronide acid. The similar fragmentation has previously been by Patora and Klimek (2002) from the leaves of Melissa officinalis. Compound 20 had a $[\mathrm{M}-\mathrm{H}]^{-}$ ion at $m / z 285$ and was assigned to luteolin aglycone. The co-elution with a standard confirmed the presence of luteolin.

Many studies were investigated polyphenol contents of $T$. grandis leaf extracts. Among of polyphenol identified only chlorogenic acid (Ghareeb et al., 2013), caffeic acid (Naira and Karvekar, 2010; Shalini and Rachana, 2009), verbascoside (Shukla et al., 2010; Singh et al., 2010) and luteolin (Shukla et al., 2010) were identified during previous studies. Others phenolic compounds were reported for the first time (namely protocatechuic acid, 2-O-caffeoylhydroxycitric acid, Caffeoyl acid derivative, 4$O$-caffeoyl quinic acid, apigenin7-O-diglucuronide, luteolin 7-O-diglucuronide, luteolin glucuronide, luteolin diglucuronide, apigenin glucuronide, luteolin glucuronide). The composition in polyphenol of our extracts was for greater part different from those of previous studies. Manah et al. (2004) was reported that polyphenol contents of plants were affected by numerous factors. These factors include genetic, ripeness at time harvest, environmental factors (soil type, sun exposure, and rainfall), processing, and storage.

\subsection{Effect of drying processes on reverse osmosis concentrate extract}

The reverse osmosis concentrate extracts were dried by freeze-drying and spray-drying to obtain powder 1 and 2, respectively. The powders obtained are all brown. As shown in Table 3, the effect of drying processes on polyphenols and antioxidant capacity from reverse osmosis (RO) concentrate extract. The amounts of polyphenols obtained after drying process are lower than those of the concentrate extract: powder $2\left(13,960 \pm 38 \mu \mathrm{mol} \mathrm{g}^{-1}\right.$ GAE) < powder $1\left(18,170 \pm 75 \mu \mathrm{mol} \mathrm{g}^{-1} \mathrm{GAE}\right)<\mathrm{RO}$ concentrate extract $\left(21,080 \pm 117 \mu \mathrm{mol} \mathrm{g}^{-1} \mathrm{GAE}\right)$. The amount of antioxidant capacity of powder $2\left(5210 \pm 5 \mu \mathrm{molg}^{-1} \mathrm{TE}\right)$ was also lower than those of powder $1\left(6980 \pm 12 \mu \mathrm{mol} \mathrm{g}^{-1}\right.$ TE) and RO concentrate extract $\left(8490 \pm 29 \mu \mathrm{mol} \mathrm{g}^{-1} \mathrm{GAE}\right)$. Recovery of polyphenol contents and antioxidant capacity in powders, were generally better than $61 \%$. Freeze-drying gave better yields (>82\%) than did spray-drying (61-67\%). Similar result was reported by Da Silva et al. (2011) when drying propolis. Phaechamud et al. (2012) also were demonstrated that thermal drying process affected significantly the amount of phenolic compounds in extract.

This study showed that freeze-drying is a good process to stabilize phenolic antioxidant from $T$. grandis leaves, as indicated by Munin and Edwards-Lévy (2011). They reported that freeze-dried particles were stable over long periods and provided to polyphenols an effective protection against oxidation phenomenon during their storage, whereas antioxidant activity remained identical.

\section{Conclusion}

T. grandis leaves extracts obtained at pilot scale contain phenolic compounds that exhibit antioxidant properties. Reverse osmosis concentrate extract have higher amount of phenolic compounds and antioxidant capacity comparatively to crude extract. In this extract, fourteen phenolic compounds as flavonoids and phenolic acids were identified and characterized. The most abundant polyphenol in this extract was verbascoside. Others compounds were reported for the first time in $T$. grandis (namely protocatechuic acid, 3-O-caffeoyl quinic acid, 2-O-caffeoylhydroxycitric acid, Caffeoyl acid derivative, 4$O$-caffeoyl quinic acid, apigenin7-O-diglucuronide, luteolin 7-O-diglucuronide, luteolin glucuronide, luteolin diglucuronide, apigenin glucuronide, luteolin glucuronide). When a concentrate extract was dried by freeze-drying and spray-drying, the freeze-dried extract has been presented a good recovery of polyphenols and antioxidant capacity. The powder form of leaf water-extracts obtained by freezedrying could be a potential advantage for preservation of its quality during storage and marketing of this traditional medicine at village level in tropical countries.

\section{Acknowledgement}

We gratefully acknowledge the French Embassy in Côte d'Ivoire for the doctoral scholarship provided to E.K. and CIRAD (DRS) for technical assistance and other financial support.

\section{References}

Adjé AF, Lozano FY, Le Guernevé C, Lozano RP, Meudec E, Adima AA, Gaydou E, 2012. Phenolic acid and flavonol water extracts of Delonix regia red flowers. Industrial Crop and Products 37, 303-310.

Apak R, Güçlü K, Demirata B, Özyürek M, Çelik SE, Bektaşoğlu B, Berker KI, Özyurt D, 2007. Comparative evaluation of various total antioxidant capacity assays applied to phenolic compounds with the CUPRAC assay. Molecules 12 (7), 1496-1547.

Aradhana R, Rao KNV, Banji D, Chaithanya RK, 2010. A review on Tectona grandis linn: chemistry and medicinal uses (Family: Verbenaceae). Herbal Tech Industry, 6-9.

Chedea VS, Echim C, Braicu C, Andjelkovic M, Verhe R, Socaciu R, 2011. Composition in polyphenols and stability of the aqueous grape seed extract from the Romanian variety Merlot recas. Journal of Food Biochemistry 35 (1), 92-108.

Da Silva FC, Favaro-Trindade CS, De Alencar SM, Thomazini M, Balieiro JC, 2011. Physicochemical properties, antioxidant activity and stability of spray-dried propolis. Journal of ApiProduct and ApiMedical Science 3 (2), 94-100. 
Fernandes A, Sousa A, Mateus N, Cabral M, De Freitas V, 2011. Analysis of phenolic compounds in cork from Quercus suber L. by HPLC-DAD/ESIMS. Food Chemistry 125 (4), 1398-1405.

Ghaisas MM, Navghare VV, Takawale AR, Zope VS, Phanse MA, 2010. Antidiabetic and nephroprotective effect of Tectona grandis linn in alloxan induced diabetes. ARS Pharmaceutica 51 (4), 195-206.

Ghareeb MA, Shoeb HA, Madkour HMF, Refahy LA, Mohamed MA, Saad AM, 2013. Radical scavenging potential and cytotoxic activity of phenolic compounds from Tectona grandis Linn. Global Journal of Pharmacology 7 (4), 486-497.

Johnson CE, Long-Ze L, Harnly JM, Oladeinde FO, Kinyua AM, Michelin R, Bronner Y, 2011. Identification of the phenolic components of Vernonia amygdalina and Russelia equisetiformis. Journal of Natural Products 4, 57-64.

Malick SAN, Bradford MJ, 2008. Recovery and stability of oleuropein and other phenolic compounds during extraction and processing of olive (Olea europaea L.) leaves. Journal of Food, Agriculture and Environment 6 (2), 8-13.

Manah C, Scalbert A, Morand C, Rémésy C, Jimérez L, 2004. Polyphenols: food sources and bioavailability. American Journal of Clinical Nutrition 79, 727-747

Meng L, Lozano Y, Bombarda I, Gaydou E, Li B, 2006. Anthocyanin and flavonoid production from Perilla frutescens: pilot plant scale processing including cross-flow microfiltration and reverse osmosis. Journal of Agricultural and Food Chemistry 54 (12), 4297-4303.

Munin A, Edwards-Lévy F, 2011. Encapsulation of natural polyphenolic compounds: a review. Pharmaceutics 3 (4), 793-829.

Naira N, Karvekar MD, 2010. Isolation of phenolic compounds from the methanolic extract of Tectona grandis. Research Journal of Pharmaceutical, Biological and Chemical Sciences 1 (2), 221-225.

Naira N, Karvekar MD, 2011. Antimicrobial and anti-oxidant properties of the isolated compounds from the methanolic extract from the leaves of Tectona grandis. Journal of Basic and Clinical Pharmacy 2 (4), $163-165$.

Nayeem N, Karvekar MD, 2010. Comparative phytochemical and pharmacological screening of the methanolic extracts of the frontal and mature leaves of Tectona grandis. International Journal of Pharma and Bio Sciences 1 (3), 1-7.

Ou B, Hampsch-Woodill M, Prior RL, 2001. Development and validation of an improved oxygen radical absorbance capacity assay using fluorescein as the fluorescent probe. Journal of Agricultural and Food Chemistry 49 (10), 4619-4626.

Pandey KB, Rizvi SI, 2009. Current understanding of dietary polyphenols and their role in health and disease. Current Nutrition and Food Science 5, 249-263.

Parveen I, Winters A, Threadgill MD, Hauck B, Morris P, 2008. Extraction, structural characterisation and evaluation of hydroxycinnamate esters of orchard grass (Dactylis glomerata) as substrates for polyphenol oxidase. Phytochemistry 69 (16), 2799-2806.

Patora J, Klimek B, 2002. Flavonoids from lemon balm (Melissa officinalis L., Lamiaceae). Acta Poloniae-Drug Research 59 (2), 139-143.

Petreska J, Stefova M, Ferreres F, Moreno DA, Tomás-Barberán FA, Stefkov
G, Kulevanova S, Gil-Izquierdo A, 2011. Potential bioactive phenolics of Macedonian Sideritis species used for medicinal "Mountain Tea". Food Chemistry 125, 13-20.

Phaechamud T, Yodkhum K, Limmatvapirat C, Wetwitayaklung P, 2012. Morphology, thermal and antioxidative properties of water extracts from Sonneratia caseolaris (L.) Engl. Prepared with freeze drying and spray drying. Research Journal of Pharmaceutical, Biological and Chemical Sciences 3 (1), 725-739.

Pooja VS, Samanta KC, 2011. Hypoglycemic activity of methanolic extract of Tectona grandis linn. Root in alloxan induced diabetic rats. Journal of Applied Pharmaceutical Science 1 (4), 106-109.

Rao KNV, Aradhana R, Banjii D, Chaitanya R, Kumar AA, 2011. In-vitro anti-oxidant and free radical scavenging activity of various extracts of Tectona grandis Linn leaves. Journal of Pharmacy Research 4 (2), 440-442.

Shalini, Rachana S, 2009. Antifungal activity screening and hplc analysis of Crude extract from Tectona grandis, shilajit, Valeriana wallachi. Electronic Journal of Environnemental Agricultural and Food Chemistry 8 (4), 218-229.

Shukla N, Kumar M, Akanksha Ahmad G, Rahuja N, Singh AB, Srivastava AK, Rajendra SM, Maurya R, 2010. Tectone, a new antihyperglycemic anthraquinone from Tectona grandis leaves. Natural Product Communications 5 (3), 427-430.

Singh N, Shukla N, Singh P, Sharma R, Rajendra SM, 2010. Verbascoside isolated from Tectona grandis mediates gastric protection in rats via inhibiting proton pump activity. Fitoterapia 81, 755-761.

Singleton VL, Rossi JA, 1965. Colorimetry of total phenolics with phosphomolybdic-phosphotungstic acid reagents. American Journal of Enology and Viticulture 16, 144-158.

Stalmach A, Mullen W, Barron D, Uchida K, Yokota T, Cavin C, Steiling H, Williamson G, Crozier A, 2009. Metabolite profiling of hydroxycinnamate derivatives in plasma and urine after the ingestion of coffee by humans: identification of biomarkers of coffee consumption. Drug Metabolism and Disposition 37 (8), 1749-1758.

Tra Bi FH, Irie GM, N'Gaman K, Mahou CHB, 2008. Études de quelques plantes thérapeutiques utilisées dans le traitement de l'hypertension artérielle et du diabète: deux maladies émergentes en Côte d'Ivoire. Sciences \& Nature 5 (1), 39-48

Vertuani S, Begheli E, Scalambra E, Malisardi G, Copetti S, Toso RD, Baldisserotto A, 2011. Activity and stability studies of verbascoside, a novel antioxidant, in demo-cosmetic and pharmaceutical topical formulations. Molecules 16 (8), 7068-7080

Wood JE, Senthilmohan ST, Peskin AV, 2002. Antioxidant activity of procyanidin-containing plant extracts at different pHs. Food Chemistry 77 (2), 155-161.

Zimmermann BF, Walch SG, Tinzoh LN, Stühlinger W, Lachenmeier DW, 2011. Rapid uhplc determination of polyphenols in aqueous infusions of Salvia officinalis L. (sage tea). Journal of Chromatography B 879 (24), 2459-2464.

Zulueta A, Esteve MJ, Frígola A, 2009. Orac and teac assays comparison to measure the antioxidant capacity of food products. Food Chemistry 114 (1), 310-316. 